\title{
Is It Difficult to Decide? Preliminary Study for Career Maturity in University Students
}

\author{
Vera Angliani Juwita
}

Faculty of Psychology, University of Jenderal Achmad Yani, Indonesia

Copyright $(2016$ by authors, all rights reserved. Authors agree that this article remains permanently open access under the terms of the Creative Commons Attribution License 4.0 International License

\begin{abstract}
It is complicated making career decision after undergraduate education, particularly for individuals who come from families with collectivistic culture. Preliminary findings study regarding the career maturity of 161 college students (73 men, 88 women, age average is 21 years) from fourth year-level at the University of Jenderal Achmad Yani, Cimahi, showed that $58.38 \%$ of respondents had a low level career maturity. Data measurements (reliability alpha $=.884$ ), based to the theory of career maturity from Crites (1978), shows the main obstacles that arise are related to the ability of goal-decision and self-efficacy in decision making. Interview's data shows that parents are still seen as the main figures that influence the decision-making of career choices.
\end{abstract}

Keywords Collectivism Culture, Career Maturity, University Students

\section{Introduction}

Families who live in a community with collectivistic culture emphasize harmony among its members. Collectivistic values emphasize the dedication of family, harmony, sociability, and a willingness to set aside personal needs for the good of the individual's social group. Self is positioned as part of the identity given by the group. Individual behavior is directed by norms and commitment or social responsibility (Markus \& Kitayama, 1991). These values have great influence on the lives of every member of the group.

At the community level, collectivity and individuality are juxtaposed, and at the individual level, self-construal dictates behaviors. The concept of cultural orientation mediates and explains the impact of culture on the social behaviors of individuals (Markus \& Kitayama, 1991). Individuals, who grew up in the collectivistic culture, will likely develop the self as interdependent. Interdependent self-construal is composed and defined through important relationships, group membership, and social roles (Cross, Gore \& Morris, 2003). Needs, desires and goals of others are more and override the individual needs when the situation is appropriate. Of course, individuals with emotional attachment have more influence, such as a member of the family or nearest social circle. In such situations, individuals with an interdependent self-construal would ignore their wishes or personal goals to adjust to the desires or goals of others (Markus \& Kitayama, 1991). It is through interdependence that individuals in collectivistic culture have to make important decisions, such as career choices.

Maturity is the key in decision-making about career choice. As stated by Crites (1978), that career maturity is the ability of individuals to make appropriate career choices, including an awareness of what it takes to make a career decision and the extent to which individual choices are realistic and the time tested. Career maturity is formed by two large dimensions, namely dimensions of knowledge and dimensions of attitude (Crites, 1978). Numerous studies show that career maturity relate to the ability in the selection majoring for study, career choice, and even the emergence of the unemployment problem (Mansor Abu Talib \& Tan Kit Aun, 2009). But career maturity can increase academic motivation (Collins, 2010), and give a positive influence on academic achievement (Seligman, 1994).

The decision making process in fact is not a single event, but rather is the result of a long development process. Many factors are involved. One of them comes from the social context, such as family relationships, the existence of the communities in which individuals live, the role of culture, the country's economy, the role of school education, the presence of friends, and the labor market (Allison \& Cossette, 2007). The social context plays a major role in the differences results of studies conducted in many countries. The study from Xue-hua Bao \& Shui-fong Lam (2008) showed that a collectivistic culture had an influence through the cultural meanings of independence, particularly in decision-making. The Chinese adolescents still perceive independence, despite not having the freedom to choose. As long as they approve and supported the choices of others, they internalized career decisions as their choice, and appreciated themselves as an independent person. Collectivism encouraged these adolescents to maintain their 
harmonization with the other people, rather than pursuit of their personal interests.

The importance of career maturity and issues of independence in decision-making for individuals from collectivistic cultures are investigated. The focus is on adolescents in Cimahi, Indonesia, who are experiencing problems in their decision making about career. Given these adolescents have grown up in a family which emphasizes values of listening and considering feedback from elders, such as parents, grandparents, and brothers. The processes of their career choices are explored in correlational study.

\section{Method}

\section{Participants}

Respondents of this study were four year-level college students from 7 faculties ( 3 faculties of social sciences, 4 faculties of non-social science) at the University of Jenderal Achmad Yani, Cimahi. The total number of respondents was 161 people, consisting of 73 men and 88 women with mean of age were 21 years. An average GPA achieved by respondents was 2.96 (GPA scale 4.00). The ethnic groups of respondents were dominated by Sundanese 64\%, Javanese $23.03 \%$ and the rest came from Sumatra, Ambon and Flores $(12.97 \%)$. The economic background of the respondents was 84. $47 \%$ from middle socioeconomic status and $15.53 \%$ came from upper socioeconomic status. Samples were taken from the population using a cluster random sampling.

\section{Instrument}

This study used a survey, through the provision of closed-ended questionnaire with a rating scale. The early part of the questionnaire contains questions on demographic data. The questionnaire presented 10 dimensions of career maturity from John O. Crites. A factor analysis (using SPSS v.18, rotation method: Varimax with Kaiser Normalization,
Rotation converged in 5 literations) showed 7 dimensions, 4 dimensions related to knowledge (self-characteristics, goal-decision, problem solving, and planning) and 3 dimensions related to attitudes (self-involvement, efficacy in decision making, and independent in choosing). The correlation for each item with their respective dimension ranged from .560 to .868 , with a reliability coefficient Alpha was .817 for knowledge scale and .819 for attitude scale.

Self-characteristics (4 items) refer to what is perceived individual about their actual condition, dealing with some process in career choice (ex. I feel confusion to answer a question what kind of job or career that I like). Goal-decision (4 items), talk about individual understanding some ways that can be done to decide career choice (ex. Doing priorities is one way that I can use when taking career decision). Problem solving (3 items) is individual actions taken in addressing the issues when deciding on a career field (ex. I'm used to find another solution if the first methods have not managed to resolve the existing problems). And, the last dimension of knowledge, career planning (3 items), behaviors that individuals use to plan actions and support career decision making (ex. I look career information that supported me to plan some courses or training that I should take to support the achievement of the future career).

Three dimensions of attitude described as follows. Self-involvement (4 items) is emergence of behaviors that reflect the initiative and willingness to accept the consequences (ex. I decided myself, majoring in education or job that I want to take later). Efficacy in decision making (3 items) is a belief of the ability in making career decision (ex. I never doubted myself in making decisions about future career options). Finally, the $3^{\text {rd }}$ dimension of attitude, independent in choosing (4 items), reflect an individual freedom when considering and choosing a career field, without need to be tied by the suggestions or demands of others (ex. My lecturer just gives advice, but my own decisions on the choice of career).

Table 1. Regression Analyze for Dimensions of Career Maturity

\begin{tabular}{|c|c|c|c|}
\hline \multicolumn{4}{|c|}{ Variables Entered/Removed ${ }^{a}$} \\
\hline Model & Variables Entered & Variables Removed & Method \\
\hline 1 & GOALDECISION & $\cdot$ & $\begin{array}{c}\text { Stepwise (Criteria: Probability-of-F-to-enter }<=.050, \\
\text { Probability-of-F-to-remove }>=.100) .\end{array}$ \\
\hline 2 & SELFCHARAC & . & $\begin{array}{c}\text { Stepwise (Criteria: Probability-of-F-to-enter }<=.050, \\
\text { Probability-of-F-to-remove }>=.100) .\end{array}$ \\
\hline 3 & INVOLVEMENT & . & $\begin{array}{c}\text { Stepwise (Criteria: Probability-of-F-to-enter }<=.050, \\
\text { Probability-of-F-to-remove }>=.100) .\end{array}$ \\
\hline 4 & PROBSOLVE & . & $\begin{array}{c}\text { Stepwise (Criteria: Probability-of-F-to-enter }<=.050, \\
\text { Probability-of-F-to-remove }>=.100 \text { ) } .\end{array}$ \\
\hline 5 & INDEPENDENT & . & $\begin{array}{c}\text { Stepwise (Criteria: Probability-of-F-to-enter }<=.050, \\
\text { Probability-of-F-to-remove }>=.100) .\end{array}$ \\
\hline 6 & EFFICACY & . & $\begin{array}{c}\text { Stepwise (Criteria: Probability-of-F-to-enter }<=.050, \\
\text { Probability-of-F-to-remove }>=.100) .\end{array}$ \\
\hline 7 & PLANNING & . & $\begin{array}{c}\text { Stepwise (Criteria: Probability-of-F-to-enter }<=.050, \\
\text { Probability-of-F-to-remove }>=.100) .\end{array}$ \\
\hline & & a. Dependent Var & RMAT \\
\hline
\end{tabular}




\begin{tabular}{|c|c|c|c|c|c|c|c|c|c|}
\hline \multicolumn{10}{|c|}{ Model Summary } \\
\hline \multirow{2}{*}{ Model } & \multirow{2}{*}{$\mathrm{R}$} & \multirow{2}{*}{ R Square } & \multirow{2}{*}{$\begin{array}{l}\text { Adjusted R } \\
\text { Square }\end{array}$} & \multirow{2}{*}{$\begin{array}{l}\text { Std. Error of the } \\
\text { Estimate }\end{array}$} & \multicolumn{5}{|c|}{ Change Statistics } \\
\hline & & & & & R Square Change & F Change & df1 & $\mathrm{df} 2$ & Sig. F Change \\
\hline 1 & $.738^{\mathrm{a}}$ & .544 & .541 & 16.25546 & .544 & 189.752 & 1 & 159 & .000 \\
\hline 2 & $.863^{\mathrm{b}}$ & .746 & .742 & 12.18261 & .201 & 125.084 & 1 & 158 & .000 \\
\hline 3 & $.929^{\mathrm{c}}$ & .863 & .860 & 8.96910 & .117 & 134.501 & 1 & 157 & .000 \\
\hline 4 & $.961^{\mathrm{d}}$ & .924 & .922 & 6.68222 & .061 & 126.850 & 1 & 156 & .000 \\
\hline 5 & $.979^{\mathrm{e}}$ & .958 & .957 & 4.98149 & .034 & 125.704 & 1 & 155 & .000 \\
\hline 6 & $.992^{\mathrm{f}}$ & .984 & .983 & 3.10749 & .026 & 244.318 & 1 & 154 & .000 \\
\hline 7 & $1.000^{\mathrm{g}}$ & 1.000 & 1.000 & .00000 & .016 & . & 1 & 153 & . \\
\hline \multicolumn{10}{|c|}{ a. Predictors: (Constant), GOALDECISION } \\
\hline \multicolumn{10}{|c|}{ b. Predictors: (Constant), GOALDECISION, SELFCHARAC } \\
\hline \multicolumn{10}{|c|}{ c. Predictors: (Constant), GOALDECISION, SELFCHARAC, INVOLVEMENT } \\
\hline \multicolumn{10}{|c|}{ d. Predictors: (Constant), GOALDECISION, SELFCHARAC, INVOLVEMENT, PROBSOLVE } \\
\hline \multicolumn{10}{|c|}{ e. Predictors: (Constant), GOALDECISION, SELFCHARAC, INVOLVEMENT, PROBSOLVE, INDEPENDENT } \\
\hline \multicolumn{10}{|c|}{ f. Predictors: (Constant), GOALDECISION, SELFCHARAC, INVOLVEMENT, PROBSOLVE, INDEPENDENT, EFFICACY } \\
\hline \multicolumn{10}{|c|}{ g. Predictors: (Constant), GOALDECISION, SELFCHARAC, INVOLVEMENT, PROBSOLVE, INDEPENDENT, EFFICACY, PLANNING } \\
\hline
\end{tabular}

Correlation between Dimensions and Career Maturity

\begin{tabular}{|c|c|c|c|c|}
\hline \multicolumn{5}{|c|}{ Correlations } \\
\hline \multirow{3}{*}{ KNOWLEDGE } & & KNOWLEDGE & ATTITUDE & CAREERMAT \\
\cline { 2 - 5 } & Pearson Correlation & 1 & $.658^{* *}$ & $.936^{* *}$ \\
\cline { 2 - 5 } & Sig. (1-tailed) & & .000 & .000 \\
\hline \multirow{3}{*}{ ATTITUDE } & $\mathrm{N}$ & $.658^{* *}$ & 161 & 161 \\
\cline { 2 - 5 } & Pearson Correlation & .000 & 1 & $.881^{* *}$ \\
\cline { 2 - 5 } & Sig. (1-tailed) & 161 & 161 & 161 \\
\hline \multirow{3}{*}{ CAREERMAT } & $\mathrm{N}$ & $.936^{* *}$ & $.881^{* *}$ & 1 \\
\cline { 2 - 5 } & Pearson Correlation & .000 & 161 & \\
\hline & Sig. (1-tailed) & 161 & & 161 \\
\hline
\end{tabular}

The last total item amounted to 25 items. Stepwise regression analysis was also performed to see the possibility of sub-dimensions that should be discarded (Table 1). The correlation between total score of career maturity with dimensions of knowledge is .936 , whereas the dimension of attitude is .881 (sig. level 0.01). The correlation dimension of knowledge with dimensions of attitude is .658 (sig. level $0.01)$.

Data were summarized using descriptive statistics, such as the mean score and standard deviation (SPSS v.18). Moreover, the nonparametric test (Mann-Whitney U) used to analyze a difference career maturity conditions for three categories, which are field of study (exact and non-exact), a gender, and a grade point average (GPA). The Pearson product moment was used in order to obtain the contribution of each dimension to career maturity.

\section{Procedures}

Data collection was assisted by three graduate students from Psychology, who previously had received an explanation of data collection procedures. Respondents were asked to rate statements presented in the questionnaire. The questionnaire also included information on informed consent which was read by the respondents before agreeing to participation in the study. This includes explanation of the purpose of the research, respondent benefits, rewards, and contact person for this research. The questionnaires were done after obtaining permission from the management faculties. Total time of completion is 7 months and effective from July 2013. From 200 sets of questionnaires distributed, only 161 were completed, for a response rate of $90 \%$.

An interview also performed to know the role of parents in the formation of interest and career decision making. Respondents were 10 students (6 women, 4 men) from 5 different Schools (Psychology, Accounting, Management, Industrial Engineering, and International Affairs).

\section{Result}

Considering the number of respondents by 
socio-economic status and ethnicity were not well proportional, such data were not included in the analysis comparing the career maturity differences. Demographic data were included in the analysis of career maturity including major field of study, GPA and gender of respondents (Vera Angliani Juwita, 2013). The following table shows the results of the Mann-Whitney test of difference for gender category and field of study.

Table 2. Comparative Test between Origin of Field Study, Sex and Career Maturity

\begin{tabular}{|c|c|c|c|}
\hline & Field Study & Sex \\
\hline Mann-Whitney U & 2103.500 & & 2880.500 \\
\hline Asymp. Sig. (2-tailed) & .128 & .260 \\
\hline \multicolumn{3}{|c|}{ SPSS v.18 } \\
\hline
\end{tabular}

Note: This data re-arrange from Vera Angliani Juwita (2013)

The comparative test (Table 2) shows that there are no differences in career maturity condition between the respondents, whether it is based on original field of study (social and non-social science), as well as by sex of respondents. Whereas for GPA, a Pearson correlation test is as follows:

Table 3. The Correlation Test for Career Maturity and GPA

\begin{tabular}{|c|c|}
\hline & GPA \\
\hline Pearson Correlation & .168 \\
\hline Sig. (1-tailed) & .016 \\
\hline $\mathrm{N}$ & 161 \\
\hline
\end{tabular}

Note: SPSS v.18, correlation is significant at the 0.05 level (1-tailed)

These findings differ from the study results from Osipow (1983) and Mansor Abu Talib \& Tan Kit Aun (2009), which focus on the influence of gender and academic achievement in a career maturity. The participation of women in the job market is not a new issue in Indonesia, although society still demands these women to prioritize their domestic roles. That is why, in this study no differences in a career maturity conditions between male and female respondents were found. Results of interviews with six female respondents indicate that they would like a career that knowledge their earned degree from the university, independence, and evidence of devotion to parents who has funds their education.

Academic achievement (GPA) is recognized as a factor that contributes to career maturity because the GPA is a measure of mastery of the subject. Mastery of subject matter usually affects student consideration in deciding his chosen career field. However, its influence in this study needs to be tested further, considering Table 3 shows that the degree of correlation between GPA with career maturity is very low. The test results showed the possibility of other factors that play a role in the career maturity of respondents compared to GPA. Alternatively, the GPA for the respondent has not been the benchmark mastery of their subject matter because the process of obtaining the GPA is not purely a personal effort from the respondents, _as motivation, intelligence, and effort also matter.

Table 4 below is shows the 6 categorization of career maturity. The data show that there are more than $50 \%$ of respondents who have a low level of career maturity. This condition cause for concern because these respondents have a range of age from 20-22 years, and only have a year to prepare for work before graduation. They need to make crucial decision on preparation for the next task development as an early adult.

Table 4. Career Maturity Limitation Categorization

\begin{tabular}{|c|c|c|c|}
\hline Categories & Knowledge & Attitude & Career Maturity \\
\hline Very Low & $2 \%$ & $1 \%$ & $3 \%$ \\
\hline Low & $6 \%$ & $14 \%$ & $24 \%$ \\
\hline Below & $54 \%$ & $37 \%$ & $32 \%$ \\
\hline Above & $22 \%$ & $32 \%$ & $27 \%$ \\
\hline High & $11 \%$ & $14 \%$ & $9 \%$ \\
\hline Very High & $5 \%$ & $3 \%$ & $5 \%$ \\
\hline
\end{tabular}

\begin{tabular}{|c|c|c|c|c|c|}
\hline \multicolumn{7}{|c|}{ Descriptive Statistics } \\
\hline & $\mathrm{N}$ & Minimum & Maximum & Mean & Std. Deviation \\
\hline SELFCHARAC & 161 & 5.00 & 40.00 & 20.3851 & 8.43954 \\
\hline GOALDECISION & 161 & 10.00 & 40.00 & 28.8758 & 4.87437 \\
\hline PROBSOLVE & 161 & 7.00 & 30.00 & 22.3602 & 3.77086 \\
\hline PLANNING & 161 & 10.00 & 30.00 & 21.8944 & 3.72593 \\
\hline INVOLVEMENT & 161 & 11.00 & 40.00 & 30.2795 & 5.21921 \\
\hline EFFICACY & 161 & 8.00 & 30.00 & 21.6149 & 4.15641 \\
\hline INDEPENDENCE & 161 & 11.00 & 40.00 & 29.7950 & 4.85685 \\
\hline Valid N (listwise) & 161 & & & & \\
\hline
\end{tabular}

*Based on Mean and Std. Deviation. SPSS vrs 18.0 
According to Super (in Sharf, 2002), the individual at the age of 21 years are at stage where they must implement a career choice. The developmental tasks that must be completed at this level is individual's capability to make a career choice, the last exploration and commitment to ensure the stability of occupational choice (Sharf, 2002). The respondents in this study have not been fully exposed to ideal conditions. There are $58.38 \%$ of respondents who have not demonstrated their readiness to close the exploration stage and immediately implement career option. That is, these respondents experienced certain constraints on the number of dimensions which measures career maturity.

Table 5 contains a number of dimensions and the percentage of respondents for each category. Out of the seven dimensions, it can be seen that there are two dimensions where $60 \%$ respondents have a total score of career maturity below average, which is goal-decision, and efficacy in decision making. Goal-decision shows the level of understanding that individuals need in deciding career goals. That is, $60 \%$ of respondents had not fully understood what they can do to make a career decision. Efficacy in decision making is a self-belief in ability to make a career decision. It can be said that $60 \%$ of respondents have less confidence that they can make a career decision.

From the correlation between dimensions (Table 6), it can be seen that the dimension goal decision has the greatest correlation with freedom in making decisions (dimensions of independence, $\mathrm{r}=.552, p=0.01$ ). The correlations show that the perceived freedom in making judgments and choosing the field of career, without being tied down with suggestions or demands of outside parties, contribute to the success of respondents choosing an effective way to make a career decision.

In addition, Table 5 shows that there are $56 \%$ of respondents who had scores below average for dimension of independence. This amount supports the correlation presented earlier, between dimension of independence and goal decision. Efficacy in decision making had moderate correlated with goal-decision $(\mathrm{r}=.496, p=0.01)$, which means that perceived efficacy in deciding career options is related to the respondent's ability to choose the right way in making a career decision. Indirectly, the dimension of independence contributes to efficacy in decision-making ( $\mathrm{r}$ $=.395, p=0.01$ ).

Table 5. Percentage of Respondent per Dimensions

\begin{tabular}{|c|c|c|c|c|c|c|c|}
\hline \multirow{2}{*}{ Categories } & \multicolumn{4}{|c|}{ Knowledge } & \multicolumn{3}{c|}{ Attitude } \\
\cline { 2 - 8 } & SC & GD & PS & Pl & Inv & EDM & Ind \\
\hline Very Low & $0 \%$ & $3 \%$ & $2 \%$ & $2 \%$ & $2 \%$ & $3 \%$ & $2 \%$ \\
\hline Low & $19 \%$ & $11 \%$ & $17 \%$ & $15 \%$ & $13 \%$ & $11 \%$ & $12 \%$ \\
\hline Below & $39 \%$ & $45 \%$ & $33 \%$ & $41 \%$ & $40 \%$ & $46 \%$ & $42 \%$ \\
\hline Above & $27 \%$ & $29 \%$ & $36 \%$ & $32 \%$ & $30 \%$ & $30 \%$ & $31 \%$ \\
\hline High & $11 \%$ & $8 \%$ & $12 \%$ & $7 \%$ & $15 \%$ & $10 \%$ & $12 \%$ \\
\hline Very High & $6 \%$ & $4 \%$ & $0 \%$ & $3 \%$ & $0 \%$ & $0 \%$ & $0 \%$ \\
\hline
\end{tabular}

Note: $\mathrm{SC}$ is self-characteristics, GD is goal-decision, $\mathrm{PS}$ is problem solving,

$\mathrm{Pl}$ is career planning, Inv is self-involvement, EDM is efficacy in decision making,

Ind is Independent in choosing. Based on Mean and Std. Deviation. SPSS vrs 18.0

Table 6. The Matrix of Pearson Correlations for Sub-Dimensions and Total Score of Career Maturity

\begin{tabular}{|l|l|l|l|l|l|l|l|l|}
\hline & S.Char & G. Decision & P. Solving & Plan. & Involve. & Efficacy DM & Indepen. & $\begin{array}{l}\text { Career } \\
\text { Maturity }\end{array}$ \\
\hline S.Char & & & & & & & & \\
\hline G. Decision & $.299^{*}$ & & & & & & & \\
\hline P. Solving & $.259^{*}$ & $.481^{*}$ & & & & & & \\
\hline Plan. & $.274^{*}$ & $.426^{*}$ & $.452^{*}$ & & & & \\
\hline Involve. & $.301^{*}$ & $.443^{*}$ & $.412^{*}$ & $.397^{*}$ & & & & \\
\hline Efficacy DM & $.237^{*}$ & $.496^{*}$ & $.478^{*}$ & $.452^{*}$ & $.487^{*}$ & & & \\
\hline Indepen. & $.229^{*}$ & $.522^{*}$ & $.490^{*}$ & $.408^{*}$ & $.411^{*}$ & $.395^{*}$ & & \\
\hline $\begin{array}{l}\text { Career } \\
\text { Maturity }\end{array}$ & $.649^{*}$ & $.738^{*}$ & $.688^{*}$ & $.656^{*}$ & $.707^{*}$ & $.688^{*}$ & $.687^{*}$ & \\
\hline
\end{tabular}

Note: Using SPSS v. 18, Pearson Correlation Test with sig. level (1-tailed) at 0.01, $\mathrm{N}=161$ 
Talk about the sub-dimensions independent, the results of interviews with 10 respondents signaled that their parents have contributed in the decision-making career choices. Eight respondents said that parents give them freedom in career choice. However, parents also expressed a certain expectation on respondent preference. For example, choosing a job which located in the same city with parents (especially for the female respondents), having regular working hours, working in corporate enterprises, helping with the family income, or choosing a job which can keep a family's honor. The family honor here refers to a prestige of parents or nuclear family in the valuation of an extended family. According to respondents, the expectations tend to be perceived as an obligation, along with the values of the necessity of the child to have filial love for the parents, and finally to embrace parental encouragement. Yet such expectations can actually limit the choice of jobs field that can be selected by respondents for their careers. However, when they must choose between personal needs with the expectations of parents, they prefer to meet the expectations. For the respondents, conflict with parents is very avoidable. They believe that parents blessing serve as a gateway of success and God's blessing.

While two respondents said that their parents had chosen a particular career field for them, which was continuing the parents' business and becoming a soldier. Not only in choosing a job, but the parents also determined and have an influenced in their children's field of study at the university. According to both respondents, their parents tended to be authoritarian. At the same time, they said that their parents are more experienced and taken decision won't harm them, so that they remain optimistic that those decisions are good for their future life. They stated he had learned from their sibling's experiences that had difficulty in their life when they did not meet the parent's expectations. In addition, they have a common understanding with eight respondents previously associated as having experience parental conflict.

The interview is an early indication that the career maturity of the respondents cannot be inseparable from parents' expectations and values embedded in the family. The respondents who listen, consider, and even follow the expectations of parents, and sacrificing personal needs; so that the relationship between the respondents with their parents remains in harmony. It is a phenomenon that usually appears in society with collectivistic culture.

As listed in Table 6, the dimensions that have a high correlation with career maturity are goal-decision $(\mathrm{r}=.738, p$ $=0.01)$ and involvement $(\mathrm{r}=.707, p=0.01)$. The correlation results indicate that career maturity shaped by an individual's ability to understand the appropriate way to make a career decision, as well as the willingness of individuals to have initiative for some necessary actions and acceptance of the consequences. All dimensions indicate the greatest correlation with the dimension of goal-decision, so it can be said that the individual's success in each dimension has a specific impact on the individual's success to understanding and choosing the right way in deciding the career choice.

\section{Conclusions}

There are a number of issues from this preliminary research on career maturity of four year-level college students at the University of Jenderal Achmad Yani. At least $58.38 \%$ of the respondents are not ready to make career decision, as well as a clear understanding of the emergence of problems in the dimensions of goal-decision and efficacy in decision making. The results showed that academic achievement as represented by GPA, field of study and gender differences have little to no effect on the career maturity of respondents. However, the limitations of the data in this initial study do not prevent answering fundamental questions about the factors that led to the emergence of career maturity and its dimensions.

Another issue that needs to be explored further in future studies relates to the findings in the dimension of independence and the results of interviews with 10 respondents. The questions that arise are whether the emergence of scores below average at $57 \%$ of respondents in the dimension of independence is influenced by parental expectations and values that are embedded in a society with a collectivistic culture? Alternatively, could this lack of career maturity be due to autonomy that has not been formed on the respondents? Or maybe, the condition of the dimension of independence is influenced by both factors simultaneously? Parents' roles, autonomy, and collectivistic culture will be a basis to construct a career maturity model for university students in the future.

\section{REFERENCES}

[1] Allison, Charlene J. \& Cossette, Mel. (1991). The Three theories of career development and choice, Washington: Edmonds Community College, 2007.

[2] Bordens, Kenneth S. \& Abbott, Bruce B. (2008). $7^{\text {th }}$ edition. Research design and method: A process approach. International edition. New York: McGraw-Hill, Inc.

[3] Brown, Steven D. \& Lent, Robert W. (2005). Career development and counseling: Putting theory and research to work. New Jersey: John Wiley \& Sons, Inc.

[4] Collins, Nancy C. (2010). A conceptual model of career development to enhance academic motivation. A dissertation: Old Dominion University. From ProQuest.

[5] Crites, J.O. (1978). The career maturity. $2^{\text {nd }}$ edition. Monterey, CA: CTB/McGraww-Hill.

[6] Cross, S.E., Gore, J. S., \& Morris M. L. (2003). The relational-interdependent self-construal, self-concept consistency, and well-being. Journal of Personality and Social Psychology, 85, pp. 933-944.

[7] Fernandez, Itziar, Paez, Dario, \& Gonzales, Jose Luis. (2005). Independent and interdependent self-construals and socio-cultural factors in 29 Nations. Revue Internationale De Psychologie Sociale, No. 1, Pp. 35-64. 
[8] Graziano, Anthony M. \& Raulin, Michael L. (2000). $4^{\text {th }}$ edition. Research methods: A process of inquiry. Boston: Allyn \& Bacon.

[9] Kaplan, Robert M. \& Saccuzzo, Dennis P. (1993). $3^{\text {rd }}$ edition. Psychological testing: Principles, applications, and issues. California: Wadsworth, Inc.

[10] Ki-Hak Lee. (2001). A Cross-cultural study of the career maturity of Korean and United States high school students. Journal of Career Development, Vol. 28, No. 1, pp 43-57. Human sciences press, inc.

[11] Mansor Abu Talib \& Tan Kit Aun. (2009). Predictors of career indecision among Malaysian undergraduate students. European Journal of Social Sciences, 8, 2, pp. 215-224.

[12] Markus, H.R. \& Kitayama, S. (1991). Culture and the self: Implication for cognition, emotion, and motivation. Psychological Review, 98, pp. 224-253.
[13] Osipow, Samuel H. (1983). Theories of career development. Englewood Cliffs: Prentice-Hall.

[14] Seligman, L. (1994). Developmental career counseling and assessment. $2^{\text {nd }}$ edition, Thousand Oaks: Sage Publication.

[15] Sharf, Richard S. (2002). Applying career development theory to counseling. $3^{\text {rd }}$ edition. California: Wadsworth Group.

[16] Vera Angliani Juwita. (2013). Career maturity for $4^{\text {th }}$ grade students at Jenderal Achmad Yani University. Cimahi: Jenderal Achmad Yani University, unpublished.

[17] Xue-hua Bao \& Shui-fong Lam. (2008). Who Makes the Choice? Rethinking the role of autonomy and relatedness in Chinese children's motivation. Journal of Child Development. March/April 2008, Vol. 79, No. 2, Pp. 269-283, The society for research in child development, inc. 